\title{
Double Standards: The Role of Gender and Intraparty Politics in Swedish Cabinet Appointments
}

\author{
Markus Baumann
}

Heidelberg University

Hanna Bäck $\odot$

\section{Lund University}

\section{Johan Bo Davidsson}

\section{Lund University}

Are female politicians less likely to be promoted to specific ministerial posts, and is it important for them to toe the party line? This article focuses on whether the selection of ministers has a gender-specific dimension. Building on role congruity theory and research showing that female and male politicians are evaluated in a different manner in leadership positions, we present some original hypotheses. For example, we hypothesize that female politicians are less likely to be appointed to cabinet when they have held gender-incongruent committee positions in parliament. We also hypothesize that women are less likely to be appointed to cabinet posts when they have previously deviated from the party line. In an empirical analysis of Swedish ministerial appointments in six cabinets, we find that female politicians were less likely to be appointed to cabinet posts when they have held positions in 'masculine' parliamentary committees and when they deviated from the party line in their parliamentary speeches. These results suggest that women are more harshly judged when

Research for this article was supported by the Swedish Research Council for Health, Working Life and Welfare (FORTE, 2013-0375). An early version of this article was presented at the EPSA General Conference, held in Milan, Italy, 22-24 June 2017. We would like to thank Stefanie Bailer, William Heller, the panel participants as well as the three anonymous reviewers for very helpful comments.

Published by Cambridge University Press 1743-923X/18 \$30.00 for The Women and Politics Research Section of the American Political Science Association.

(C) The Women and Politics Research Section of the American Political Science Association, 2018 doi:10.1017/S1743923X18000673 
holding positions that are not in line with traditional gender stereotypes and have important implications for our understanding of gender and political leadership.

Keywords: cabinet appointments, role congruity theory, intraparty politics, female politicians, ministerial selection

In many countries, women hold an increasing number of seats in parliament, and they are appointed to more and more cabinet posts. In some countries, we can now even speak of cabinet parity. However, the selection of women to political leadership positions does not appear to be gender neutral. Women are, for example, more likely to be appointed to cabinet posts with lower prestige (Davis 1997; EscobarLemmon and Taylor-Robinson 2009; Reynolds 1999; Studlar and Moncrief 1997). They also face a different, and often more demanding, set of expectations and conditions, often in relation to leadership selection: women candidates encounter gender biases in recruitment processes (Lawless 2015; Niven 1998; Sanbonmatsu 2006), and female party leaders tend to be selected under more electorally challenging circumstances (O'Brien 2015). Previous research has clearly shown gender biases in political leadership selection (Krook and O'Brien 2012; O'Brien 2015).

Research on what determines the selection of women to political leadership roles has been dominated by institutional and sociological explanations. According to the former, electoral systems, government types, and constitutional quotas aid or impede the selection of women as cabinet ministers or party leaders (Escobar-Lemmon and TaylorRobinson 2005; Iversen and Rosenbluth 2008; Krook and O'Brien 2012; Reynolds 1999; Siaroff 2000). Sociological approaches explain the crosscountry variation in the representation of women in cabinet positions and among party leaders by focusing on supply or demand arguments. A large share of women in the labor force, or in political positions, increases the number of viable candidates, and the level of women's economic power affects the value orientations of a society, leading to a higher acceptance of female candidates (Blumberg 1984; Iversen and Rosenbluth 2008; Krook and O'Brien 2012). Although these are important contributions, these explanations say little about the political 
dynamic within parties or cabinets, where the selection processes that lead to gender biases occur.

To get at those selection processes, in this article, we draw on existing literature on ministerial selection (see Dowding and Dumont 2008). This literature accounts for ministerial selection based on a number of key determining factors: the effect of individual background on political representation and ministerial selection (e.g., Blondel and Thiébault 1991); parliamentary background and behavior that facilitate selection, such as parliamentary tenure and prominence (e.g., De Winter 1991); and strategic considerations (e.g., Dowding and Dumont 2008; Kam et al. 2010). We build on previous insights from this literature, using principal-agent arguments, to contribute to our understanding of the role of gender and intraparty politics in ministerial selection.

The principal-agent approach to ministerial selection takes as a starting point that ministers, once they have been selected, have motives and opportunities to act in their own interest rather than that of the prime minister (PM), who is often perceived as the dominant principal. A solution to this problem is to select ministers who have preferences closely aligned to those of the principal (e.g., Kam et al. 2010). We analyze how gender interacts with the policy positions of individual members of parliament (MPs), drawing on previous research showing that female and male politicians are evaluated differently in leadership positions (see, e.g., Eagly and Karau 2002). We ask whether, in processes of ministerial selection, the demands of the principal differ between female and male ministerial candidates. For example, are female politicians sanctioned more for deviating from the party line than male politicians when ministerial offices are being allocated?

We answer this question using data on cabinet appointments from Sweden. The Swedish case represents a particularly critical test for several reasons. Given the egalitarian character of Swedish society and the high level of female labor-market participation, the main sociological explanations in the literature predict a low risk of gender bias. Institutional explanations lead to a similar expectation; Sweden uses a proportional representation electoral system with party lists and gender quotas and has near gender parity in parliament. Finally, an important characteristic of the research period under study here is gender parity in cabinets, which has been established (and complied with) as an informal rule since the 1990s. Taken together, these characteristics make Sweden an unlikely case for gender biases, and we would expect little, if any, impact of gender in processes of ministerial selection. If, on the contrary, 
we detect gendered processes of ministerial selection in this case, institutional arrangements may not suffice to eradicate all gender bias and would suggest that gender biases in politicians' career development may operate in a concealed manner.

To empirically test whether deviation from the principal affects the chances of selection differently between male and female candidates, we estimate policy positions of Swedish MPs based on computerized content analysis of their speeches given before appointment to cabinet. Analyzing Swedish ministerial appointments across six cabinets between 1996 and 2014, we find, similarly to previous research, that the policy distance between a member of parliament (MP) and the party matters for ministerial selection. However, this effect is much stronger for female MPs. In other words, deviating from the party line means that you are less likely to be appointed to the cabinet, particularly if you are a woman and, hence, that as a woman you are more harshly punished for not toeing the party line.

In addition, we also evaluate how gendered assignments to ministerial posts affect political careers on their own. From a theoretical perspective, we expect these effects to be related to role incongruity (Eagly and Karau 2002), which leads us to contend that female politicians should suffer from holding role incongruent positions. More specifically, we expect that female MPs are less likely to be recruited for "masculine" ministerial posts (Krook and O’Brien 2012, O’Brien 2015). Building on findings related to gendered committee assignments (Bolzendahl 2014), we argue that female MPs who have been members of typically masculine committees face lower chances to be recruited as cabinet ministers. Although the first expectation is well established in the literature (Krook and O'Brien 2012), we do not find robust empirical support in the case of Sweden. In relation to role-incongruent committee assignments, female politicians who have served in typically masculine committees have lower chances of attaining ministerial posts. Together with the result that female politicians seem to be more harshly punished for deviating from the party line, this result strongly suggests that gender biases exist in ministerial selection in Swedish cabinets. These biases are in line with role-congruity theory and its predictions about gender stereotypes, which has important implications for our understanding of gender and political leadership. 


\section{PREVIOUS RESEARCH ON GENDER AND LEADERSHIP SELECTION}

In this section, we review the three strands of literature that we draw on to make predictions about gendered processes in ministerial selection. Our research interest lies at the intersection of partisan strategies in ministerial selection and gendered processes in the parliamentary career development of politicians. For the former, we present the key contributions and findings of the recent literature that has looked at portfolio allocation and ministerial selection in coalition governments. For the latter aspect, we draw on and review two strands of literature: previous work on the gender dimension of political careers, and role congruity theory. After this review, we develop our expectations for the Swedish case.

\section{Literature on Ministerial Selection}

The literature on ministerial selection takes its starting point in the "parliamentary chain of delegation," which suggests that power relationships in a parliamentary democracy can be described as a chain, where citizens in a first step delegate power to representatives, who in turn delegate to a cabinet and a PM, who delegates power to line ministers (see, e.g., Strøm 2000). Applying principal-agent theory to ministerial selection, the principal faces a problem of adverse selection because, at the time of appointment, the principal does not have complete information about a minister's abilities and preferences to run a department in accordance with the wishes of the principal. Moral hazard problems can arise in this relationship because, as described by Indridason and $\operatorname{Kam}$ (2008, 624), "All ministers have motive and opportunity to use their portfolios in a manner that runs against the principal's interests."

To minimize agency problems, specifically, to ensure that line ministers act in a way that coincides with the wishes of the principal, the principal can appoint ministers whose interests do not clash with the principal's interest, which implies selecting ministers with policy positions close to the main principal (Bäck, Debus, and Müller 2016; Kam et al. 2010). Kam et al. (2010) focus on the single-party governments formed in the United Kingdom and present two competing hypotheses. The first, the so-called "leadership hypothesis," characterizes the party leadership as the main principal, and the second, the "party government hypothesis," portrays the party backbenchers as a "collective" principal, suggesting 
that potential ministerial candidates should be ideologically close to these principals to get appointed. Bäck et al. (2016) instead focus on coalition systems in Western Europe, and they suggest some additional potential principals in such systems; most importantly, the coalition as a whole may act as a principal in addition to the PM.

Following this literature, we let the institutional setting guide the choice of principal. Because Sweden, which is analyzed here, is characterized by relatively weak PMs, we do not focus on the PM as a main principal here (see, e.g., Bergman et al. 2003). Instead, we have followed the work by Carey (2007), who suggests that, in representative democracies, ministers must always answer to their parties and face their own party as a principal. Therefore, we assume that the party is the main principal to whom ministers are accountable, and whose preferences ministerial candidates should be close to be appointed to the cabinet.

\section{Literature on Gender and Political Appointments}

An important empirical finding in the literature on the role of gender in political leadership is that women tend to be underrepresented in higher positions in the political hierarchy. Previous research shows that women are less likely to obtain a ministerial post, and when they do attain ministerial offices, they are likely to hold less prestigious posts (Escobar-Lemmon and Taylor-Robinson 2005; Krook and O’Brien 2012; Reynolds 1999).

The literature on female representation, however, suggests not only a 'vertical division of labor' between women and men but also a 'horizontal division of labor' in which women are often seen in specific posts, dealing with policy issues that have been described as being 'softer.' For example, Reynolds $(1999,564)$ finds “a worldwide tendency to place women in the softer sociocultural ministerial positions rather than in the harder and politically more prestigious positions of economic planning, national security...." Krook and O'Brien (2012, 842) suggest that the relationship between women and more 'feminine' cabinet assignments, such as ministerial portfolios dealing with social welfare policy, may be due to a number of reasons, such as women's specific interests, or that certain ministries are perceived as being closer to

1. Similar patterns have been found for committee appointments, where women are more likely to be members of 'feminine' committees. Bolzendahl (2014) shows, analyzing data on committee appointments over 40 years in Sweden, Germany and the United States, that women are overrepresented on committees dealing with for example social insurance, culture, health, and welfare (see also Wängnerud 2015). 
women's concerns. Such gendered patterns may be "rooted in efforts to marginalize women or in the preferences of female cabinet appointees."

However, Krook and O'Brien $(2012,853)$ also argue that these gendered patterns in ministerial selection are beginning to change, stressing that several leaders have appointed cabinets characterized by gender parity and that women are increasingly nominated to more 'masculine' and high-prestige portfolios. A striking finding in their analysis of cabinet appointments in 117 countries (in 2009) is that women's appointments are to a large extent explained by the presence of more women among political elites, which they stress can partly be promoted by concrete political strategies, such as gender quotas.

\section{Social Psychological Literature on Role Congruity}

One important theory in the field of gender and leadership is the so-called "role congruity theory of prejudice," advanced by Eagly and Karau (2002), which suggests that perceived incongruity between the female gender role and leadership roles leads to prejudice and bias against women in leadership positions. Eagly and Karau $(2002,574)$ suggest that beliefs about gender roles refer to both descriptive and prescriptive expectations associated with men and women, that is, such gender role beliefs for example describe how we expect women to behave in a specific situation and what people believe women ought to do. Therefore, they are based both on stereotypes about women and men and on social norms. A key proposition of this approach focuses on what has been called 'agentic' and 'communal' attributes: men are valued for being 'agentic' and are expected to be more assertive, controlling, dominant, and "prone to act as a leader." In contrast, women are expected to be more 'communal,' which entails that they are assumed to be more concerned with the welfare of other people and to be more helpful, nurturing, and sensitive (Eagly and Karau 2002, 574; Kite, Deaux, and Haines 2008; Rudman 1998; Rudman and Glick 2001).

Eagly and Karau's (2002, 575-576) role congruity theory predicts prejudice toward women in leadership positions, resulting from a dissimilarity in the expectations that people have about women and the expectations that people have about leaders. They argue that prejudice toward female (potential) leaders takes two forms: "(a) less favorable evaluation of women's (than men's) potential for leadership because leadership ability is more stereotypical of men than women and (b) less favorable evaluation of the actual leadership behavior of women than 
men because such behavior is perceived as less desirable in women than men." The latter proposition suggests that female leaders may be negatively evaluated even when they fulfill their leadership roles because being effective leaders may "violate standards for their gender" when women display such agentic attributes.

Empirical findings on gender and leadership also seem to support the theory of role congruity. For example, Brescoll, Dawson, and Uhlman (2010) show, using an experimental design, that women who are in gender-incongruent positions (e.g., female police chiefs or college presidents) are more harshly judged when they make a mistake. Studies applying the role congruity theory of political leadership are still relatively scarce. However, in a large comparative study of party leadership selection, O'Brien $(2015,1)$ shows that men and women have "differential access to, and experiences in, party leadership." She hypothesizes that female party leaders are more likely to be fired from their posts when the party performs badly in the polls, drawing on the work by Eagly, Makhijani, and Klonsky et al. (1992), which shows that female leaders are likely to be devalued when they hold leadership roles that are traditionally male dominated. Hence, O'Brien (2015, 11) suggests that "female leaders are likely to be held to higher standards than their male counterparts," and she finds support for this argument when analyzing party leadership selection and deselection in parliamentary democracies.

\section{Hypotheses about the Role of Gender in Ministerial Selection}

To specify our hypotheses, we have drawn on all the literature described in the previous section, and we also take the specific setting in Sweden into account. Cabinets in Sweden have been, to a large extent, characterized by gender parity. As Bäck et al. $(2009,163)$ describe, Olof Palme was the first PM to acknowledge the gender dimension in the recruitment of ministers, and the following PM, Ingvar Carlsson, made an official promise in the 1994 election campaign, to appoint as many women as men to his new cabinet. Since then, female representation in Swedish cabinets has been high in comparison to many other contexts (approximately 50\%). Hence, we do not expect that women are less likely to be appointed to cabinet when looking at the Swedish case. However, we aim to evaluate the argument from the existing literature on gender and political appointments, which has found that female 
candidates are more likely to be selected to posts in 'feminine' policy areas (Krook and O'Brien 2012). Thus, we formulate the following hypothesis:

H1: Female politicians are more likely to be appointed to ministerial posts controlling feminine policy areas.

The underlying mechanism proposed in the previous literature is that gendered appointment patterns may be rooted in a marginalization of women or in the preferences of female candidates for cabinet (Krook and O'Brien 2012: 842). However, this hypothesis can also be connected to role-congruity theory (Eagly and Karau 2002). This theory posits that prejudice is likely to arise against female potential candidates for ministerial posts, especially posts that deal with policy areas considered less feminine (e.g., defense, finance), since role incongruity would be even higher for such posts than for ministerial posts on average. According to this line of reasoning, we expect role incongruity to matter prospectively, that is, we expect that party leaders would not recruit female ministers to certain "masculine" ministerial portfolios to avoid situations of role incongruity during the lifespan of the government.

Similar to the finding that ministerial recruitment is gendered (Krook and O'Brien 2012), recent literature has shown that legislature committee systems emphasize the same gender-typed roles, with female legislators specializing, for example, in social policies and education (see, e.g., Bolzendahl 2014). Against the backdrop of role incongruity theory, we contend that gendered committee profiles may lead to "retrospective" role incongruity:

H2: Female politicians who are members of "masculine" parliamentary committees are less likely to be appointed to ministerial posts.

The argument for this second hypothesis is, as specified by role congruity theory, that women who hold role-incongruent positions are more harshly judged and are therefore less likely to advance in their careers (and to enter cabinet positions) when they are holding positions in parliament that are perceived as being highly incongruent with their gender.

In our third hypothesis, we draw on work that sees ministerial selection as a delegation problem where the aim of the principal is to mitigate problems of agency loss, more specifically moral hazard, by relying on ex ante screening mechanisms. How can the principal ensure that the line ministers act in accordance with his or her wishes? As Kam et al. (2010) argue, one answer is to select those individuals for cabinet membership whose policy preferences are as close as possible to the principal's own 
preferences. Another reason for appointing politicians who do not deviate from the party line could also be that the party leadership is interested in rewarding "loyalty." Following the literature on so-called "mega seats" (see Carroll, Cox, and Pachón 2006), MPs are more likely to toe the party line to be rewarded with prized postelectoral positions such as ministerial posts, the post as speaker of parliament, or in some systems, committee chairs (see, e.g., Bäck and Debus 2016; Martin 2012). Rewarding loyalty would have a similar impact on ministerial selection as a mechanism relying on a principal-agent logic.

Hence, in general, it should be positive for a politician's career prospects to toe the party line. We are specifically interested in how gender interacts with deviations from the principal's preferences in ministerial selection processes; therefore, we specify a hypothesis focusing on gender:

H3: Female politicians who deviate from the party line are less likely to be appointed to ministerial posts.

To clarify the proposed mechanism underlying this effect, we again draw on gender-congruity theory, which suggests that women who hold genderincongruent positions are more harshly judged. Women candidates for cabinet, who deviate from the party line, from this perspective, could induce a stereotyping behavior on the part of the principal in which women who deviate are considered too agentic, or conversely, not communal enough. The principal would be less accepting of female, compared to male, political mavericks and backbenchers in cabinet appointments. Here, we suggest that two alternative mechanisms related to gender roles may be at work: (a) female politicians may be in general more harshly evaluated and scrutinized, or (b) female politicians may be subject to other expectations about what traits they should exhibit. We expect that loyalty is a more communal trait, in line with traditional female gender roles. Both mechanisms suggest that female politicians are more likely to be sanctioned when they deviate from the party line and that they are less likely to become ministers if they do not toe the party line.

\section{DATA AND METHODS}

\section{Ministerial Selection in Sweden}

Evaluating our expectations require gathering information on portfolio allocation, ministerial recruitment, individual MP characteristics, their parliamentary behavior, and their intraparty positioning in a longitudinal 
research design. The country and period selected are theoretically interesting for several reasons. First, Sweden has had a stable party system since World War II in which parties have persisted due to their ability of maintaining a sense of collective identity (Gallagher, Laver, and Mair 1995; Mair 1997). This stability in the composition of partisan actors also held from 1996 to 2014. Nevertheless, elections have resulted in shifting parliamentary majorities, but without causing landslide victories that could have replaced large numbers of MPs. This stability in the make-up of parliament enables us to disentangle how individual MP behavior in previous periods affected an MP's chances for ministerial recruitment. Second, the selected period covers several governments from both sides of the ideological spectrum, and coalition and singleparty governments as well as minority and majority governments (see, e.g., Bäck and Bergman 2016). In Table 1, we have described the cabinets that formed during the study period.

Ministerial selection in Sweden has been described by Bäck et al. (2009, 159-160), who suggest that the PM candidate is relatively free to staff the cabinet as he or she wants, even though informal constraints from other parties' leaders are likely to influence selection in coalition governments (see, e.g., Bäck et al. 2016). Notably, the number of female cabinet ministers is high; most cabinets formed during the study period are in fact characterized by gender parity (Table 1). Considering that gender representation in the Riksdag is in some cases actually lower than in cabinet, with female representation hovering around 45\% during the period analyzed here (see, e.g., Bäck and Debus 2016), being a woman does not negatively affect a politicians' chances of entering the cabinet. In sum, by choosing the Swedish case, we deliberately focus on a critical case for our theory: ministerial recruitment is less likely to be affected by gender biases in Sweden than in most other parliamentary democracies.

\section{Dependent Variable and Modeling Strategy}

The dependent variable in our analyses is a binary indicator for ministerial selection. Each MP in our data can, potentially, be selected to become a minister at each government reshuffle and in each policy area or ministry. Government reshuffles are defined along the formation of new cabinets. Our dependent variable thus covers the ministerial selection processes for 1996, 1998, 2002, 2006, 2010, and 2014. ${ }^{2}$ Ministries were coded along the policy areas, for which they assign responsibility to the 
Table 1. Governments formed during the study period

\begin{tabular}{lllllc}
\hline Cabinet & PM's Party & Year In & Parties Included & $\begin{array}{c}\text { Minority } \\
\text { Cabinet }\end{array}$ & $\begin{array}{c}\text { Female } \\
\text { Ministers, \% }\end{array}$ \\
\hline Persson I & $\begin{array}{c}\text { Social } \\
\text { Democrats } \\
\text { Pocial } \\
\text { Democrats }\end{array}$ & 1996 & Social Democrats & Yes & 42 \\
Persson III & $\begin{array}{c}\text { Social } \\
\text { Democrats } \\
\text { Moderates }\end{array}$ & 2002 & Social Democrats & Yes & 49 \\
Reinfeldt I & 2006 & $\begin{array}{c}\text { Centre Party, Democrats } \\
\text { Moderates, Liberals, } \\
\text { Christian Democrats }\end{array}$ & Yes & 52 \\
Reinfeldt II & Moderates & 2010 & $\begin{array}{c}\text { Centre Party, } \\
\text { Moderates, Liberals, } \\
\text { Christian Democrats } \\
\text { Löfven }\end{array}$ & $\begin{array}{c}\text { Social Democrats, } \\
\text { Greens }\end{array}$ & Yes \\
\hline
\end{tabular}

Comment: From Bäck and Bergman (2016), updated by the authors.

respective minister. This enables abstracting from changes in the composition of ministries, which change over time. The coding for the ministerial policy areas allocated ministerial posts to 40 categories, of which 25 were used during our observation period. For each policy area in each cabinet formation, we coded the ministers selected with 1 , and 0 otherwise. This creates a data structure with one observation for each potential candidate (MP) in each policy area and each cabinet formation. Since opposition MPs are (typically) not eligible to be appointed to the cabinet, we restricted our empirical models to MPs who are members of the governing parties. The MPs from the governing parties were thus our 'pool of candidates.'

2. The first cabinet formation in our observation period (1994) is not used for the dependent variable because the independent variables covering parliamentary behavior (e.g., speaking habits) require gathering information prior to the cabinet formation.

3. Hence, we assume that the government formation process is already completed in the sense that the parties have agreed on which parties should form a government. This is, of course, a simplifying assumption, as some politicians may already be considered as likely ministers even before the parties have come to a complete agreement about entering government together. However, this assumption is typically made in the literature on portfolio allocation (see, e.g., Bäck et al. 2011), and no alternative multivariate methodological approach has been presented in the literature that would allow us to model the allocation of ministerial posts and government formation simultaneously. In addition to restricting our sample to MPs from the governing parties, we are only able to analyze those MPs who had held a speech in parliament during the legislative period - otherwise, they had a missing value and we could not analyze their policy positions. Thus, the analyzed number of MPs 
To evaluate our hypotheses, we follow and further develop the framework used by Bäck, Debus, and Dumont (2011), who model selection as a discrete choice where the unit is each post to be allocated in a formation opportunity and the parties are the alternatives, applying a conditional logit model. Our dependent variable reflects whether an MP was successful in being selected as a minister in one of the 25 policy fields in each cabinet formation process. We apply conditional logit models that use a combination of the cabinet formation and policy area as groups. The individual politicians are considered the pool of candidates for becoming ministers in each policy area; thus, they are the "alternatives" in this discrete choice model.

\section{Predictors of Ministerial Selection}

Our independent variables cover four broad fields of an MP's qualification for a ministerial appointment. First, we include information on an MP's intraparty positioning as an ideological outlier within the party or as one who follows the party line. Second, we use information on an MP's gender. Third, we expect female MPs to be assigned only to certain ministries; thus, we employ measures that capture the gender type (Krook and O'Brien 2012) of a ministry, that is, whether a ministry can be characterized as feminine, masculine, or neutral. Lastly and related to our expectation of retrospective role congruity, we include variables that capture the gender-type of the committees an MP was a member of, that is, whether he/she was a member in committees that could be characterized as feminine, masculine, or neutral (see Table Al in the Appendix for more detailed information).

The MP-related information in our data set is coded in a dynamic data arrangement. That is, the data combines static information on MPs that did not change throughout their time in parliament (e.g., occupation, gender, etc.) with information that did change during their time in parliament. For the latter set of variables (e.g., age or tenure), we coded specific observations that indicate the beginning and end of the observation to identify an MP's most recent position before a ministerial selection took place. We assume that parliamentary behavior is dependent on the role an MP played in parliament (e.g., chairing a committee), and for each each period, see Table A2). 
MP in each ministerial selection process, we use the most recent observation that exceeded 90 days. ${ }^{4}$ This approach has two advantages: First, it allows us to construct the variables reflecting parliamentary behavior (i.e., positioning in speeches) based on the most recent information on MPs and to abstract from previous, dated information. ${ }^{5}$ Second, we are able to include information on ministers who had not been MPs directly before the recruitment process but had been previously during our observation period.

Individual intraparty positioning is operationalized through quantitatively analyzing MPs' speaking behavior in plenary debates (before being appointed as ministers). ${ }^{6}$ We therefore gathered all speeches held during our observation period. To estimate MPs' ideological positions, we rely on computer-based quantitative content analysis and applied Wordscores models (Laver, Benoit, and Garry 2003). Wordscores is suitable for drawing inferences when studying the content of parliamentary speeches (e.g., Bäck and Debus 2016; Baumann, Debus, and Müller

4. Note that the 90-day duration is a minimum requirement. For the vast majority of MPs, the observation periods include full legislative terms. This is the case for all MPs who did not change in their committee affiliation or intraparty posts during a term. Detailed descriptive information on the durations of the periods that underlie our measures is provided in Table A2 in the Appendix.

5. Take, for instance, a situation in which the party chair position changes from one MP to another. Without dividing observations within terms, we would either have to consider both MPs as chairpersons or none. In our approach, we correctly identified the chair in office at the point of cabinet formation.

6. Of course, alternative sources could be used to measure MPs' policy positions and their deviations from the party line. For example, some scholars rely on MP surveys (see, e.g., Kam et al. 2010). The MP surveys performed in association with each Swedish parliamentary election could potentially be used (see, e.g., https://www.gu.se/forskning/publikation?publicationId=223194 for info on the 2014 survey). Identified data from these MP surveys are not freely available, which made it impossible to analyze ministerial selection using such measures. Another alternative source of measurement that is often used in US studies of individual legislators' policy position are so-called roll-call data (see, e.g., Krehbiel 2000; McCarty, Poole, and Rosenthal 2006), for example using the dynamic scaling technique, DW-NOMINATE (Poole and Rosenthal 1997). However, as described by Carroll and Poole (2014), such measures are not as useful in measuring preferences of individual legislators in European parliaments, due to the high level of strategic voting behavior among MPs in most parliamentary systems. As described by Carroll and Poole (2014): "In situations where strategic voting is widespread - where voting is motivated by factors unrelated to one's preferences regarding the content of the policies under consideration - one cannot assume that the variation in the data can be reasonably interpreted as reflecting the preferences of individual legislators. [...] in systems with very high party discipline, defections may not be directly a function of preferences and therefore will not provide reliable preference information on the individuals within the party." Sweden is clearly a case in which party discipline in voting is very high (see, e.g., Lindvall et al. 2017, 144). Willumsen and Öhberg (2017) analyze the Swedish Riksdag and show some evidence for that MPs' individual policy positions matter for their likelihood of defecting from the party line when voting, but they also show that the strongest effect on roll-call voting clearly comes from whether he or she belongs to the governing party or not. Overall, we suggest, following Carroll and Poole (2014) that it is questionable to use roll-call data for the specific purpose of analyzing deviations from the party line in a parliamentary democracy like Sweden. However, for obtaining measures of policy positions at the party level, and for analyzing voting unity, such data are clearly valuable. 
2015; Bernauer and Bräuninger 2009; Giannetti and Laver 2009; Laver and Benoit 2002).

We use all speeches given by an MP during our observation periods, but we calculate individual positions based on MPs changing roles. For instance, if an MP became a committee chair during the term, we calculate positions for the period prior to this change and for the period following the chair appointment. Furthermore, our positions are specific to the policy area that corresponded to a ministry: for each MP we derive separately a position based on the speeches given in this policy area. With this approach, we can determine whether an MP deviated from her parliamentary colleagues in the policy areas that are relevant to the post to be filled. Because policy-specific reference scores are difficult to obtain from manifesto data or expert surveys, we assigned all policy fields to either the gal-tan (green-alternative-libertarian vs. traditional-authoritariannationalist) or the left-right dimension (economic left vs. economic right), as used by the Chapel Hill expert surveys (Polk et al. 2017). As reference texts for our scaling models, we relied on the manifestos of the respective party in the previous campaign. Based on these scores, we identify the position an MP occupied within the party in a policy field. We operationalize this position by calculating the difference between an MP's position and her parliamentary party group's mean position in each policy field (see also Baumann, Debus and Klingelhöfer 2017).

In investigating the effects of an MP's gender and intraparty positioning in ministerial recruitment, we control for several (individual-level) factors identified in the literature. Most importantly, we need to control for MPs who are part of the party leadership or who are otherwise prominent because these parliamentarians are most likely to secure a ministerial appointment. Thus, we include a binary measure indicating whether an MP was a member of the party leadership (party leader) and the share of speeches that MP gave relative to all speeches given by her party group (prominence). Similarly, we expect MPs who have specialized in a certain policy field to be recruited more frequently. We measure this by calculating the share of speeches an MP devoted to the respective issue areas relative to all the speeches she gave in parliament (specialization). In addition, we include several variables that have been identified to be influential by the previous literature on ministerial careers (Blondel and Thiébault 1991; De Winter 1991). This includes an MP's age and tenure, along with a binary indicator for MPs with university degrees or similar higher education (high education). Lastly, we include the standard errors of our Wordscores estimates as a technical control variable. ${ }^{7}$ 


\section{The (Incomplete) Pool of Ministerial Candidates}

This approach to analyze ministerial selection, that is, analyzing speeches made in parliament before appointment, comes with one significant limitation. In a context where ministers are sometimes appointed from outside parliament, that is, where many ministers are appointed without having any political background, we can not fully capture the entire pool of ministerial candidates. In an important study of ministerial selection, which we have drawn on here, Kam et al. (2010) analyze the British case, which has the advantage that ministers should be drawn from parliament, so a fixed set of politicians are candidates for cabinet offices. ${ }^{8}$ In most other parliamentary democracies, this is not the case; for example, Cotta (2018) shows, on the basis of a study of 14 European countries, that the share of nonpartisan ministers varies between 16\% and 58\%. As described by Bäck and Persson (2018), the Swedish case does not stand out in this regard, with approximately $25 \%$ nonpolitical ministers during the postwar period.

Nonetheless, we are dealing with an incomplete pool of potential ministerial candidates here, which may result in some bias if ministers from outside cabinet are selected on a different basis than ministers drawn from parliament. Looking at descriptive information about the politicians appointed in Swedish cabinets (see Table A3 in the Appendix), there is no clear structure in the gender-balance of ministers that were MPs at their appointment, were MPs previously, or had never been an MP at the time of appointment. Despite the lack of a clear gender bias and the differences between cabinets, the nuanced differences may suggest that fewer women are able to make it to cabinet through a political career. ${ }^{9}$ Hence, we must use caution when interpreting the results of this study because we cannot be certain that our results about the role of gender in ministerial selection would hold if applied to an 'outsider' sample. We discuss this aspect further in the conclusions.

7. Standard errors for Wordscores indicate how certain an estimated position is and will generally be larger for positions that have been derived from smaller amounts of text. We include the variable as a technical control to avoid biases where extreme but uncertain positions result in large deviations. Among other such biases, this approach avoids effects related to the different durations of the underlying observation periods.

8. Even in the Kam et al. (2010) study of the British case, there are individuals missing from the pool of candidates: the MP surveys used to measure the MPs' policy positions have response rates between $44 \%$ and $67 \%$.

9. This is, in fact, in line with our third hypothesis, that female politicians may be punished within the party, which would render it necessary for the party leadership to look elsewhere to achieve gender parity in the cabinet. 


\section{EMPIRICAL ANALYSIS}

\section{Descriptive Analyses: The Policy Deviations of Swedish Politicians}

Our Wordscores models allow us to identify individual positions for each MP. This position is derived from the most recent observation before a cabinet recruitment we have for an MP. Table 2 provides descriptive statistics for this deviation and for our dependent and independent variables.

Figure 1 graphically illustrates MPs' policy-field-specific deviation across the six cabinet formation processes that we study. The deviations are grouped along a politicians' status as either ministers or MPs and along gender lines. The figure indicates that on average MPs who have been appointed a cabinet post (labeled "Minister") had lower deviations prior to their recruitment than their unsuccessful colleagues. This finding supports our baseline expectation that MPs who deviate from their parties' policy position in a certain policy field are less likely to be recruited to ministerial posts in the respective field.

When comparing deviations across politicians' gender, we detect no striking differences, neither between female and male ministers, nor between female and male (nonminister) MPs. However, we expect the effect of gender on ministerial recruitment to be a complex process which is - above all - conditional to the policy field to which the respective ministry pertains. Thus, we use a multivariate analysis to test our hypotheses.

Table 2. Descriptive statistics

\begin{tabular}{lcrcccc}
\hline & Observations & Mean & $\begin{array}{c}\text { Standard } \\
\text { Deviation }\end{array}$ & Minimum & Maximum \\
& & & .05 & .21 & 0 & 1 \\
Minister (binary) & 50,600 & .45 & .5 & 0 & 1 \\
Female MP (binary) & 50,600 & 57.95 & 9.82 & 18.79 & 79.35 \\
Age & 50,600 & 50,600 & 5.96 & 6.17 & 0 & 43.76 \\
Parliamentary tenure & 50,600 & .57 & .5 & 0 & 1 \\
Academic education (binary) & 50,600 & .04 & .2 & 0 & 1 \\
Party leadership position & & & & & 1.3 \\
$\quad$ binary) & 30,140 & .02 & .04 & 0 & .87 \\
Deviation in policy field & 50,600 & .09 & .1 & 0 & 1 \\
Prominence in plenary debates & 50,600 & .05 & .14 & 0 & 1 \\
Specialization in policy field & 50,600 &
\end{tabular}

Comment: Observations are combinations of policy fields and MPs who were considered candidates in the six cabinet formation processes. The total number of MPs coded is 812 . 


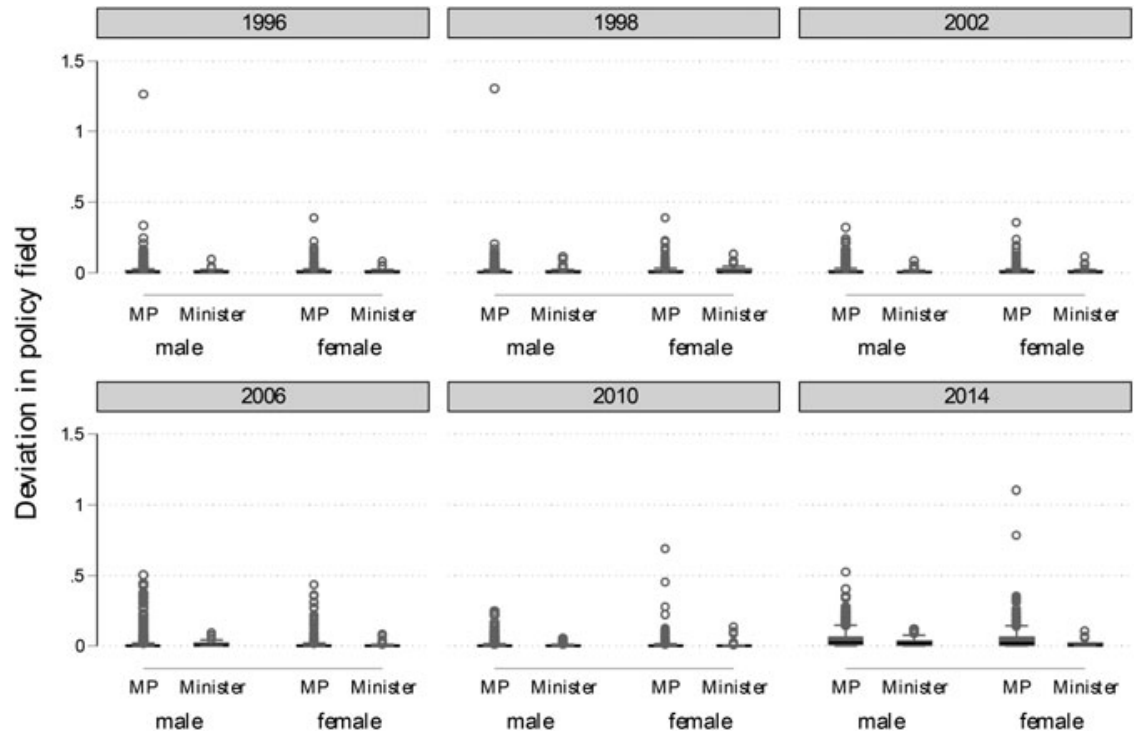

Figure 1. Deviation from the party position for female and male ministers and MPs across cabinet formation processes.

\section{A Multivariate Analysis of Ministerial Selection}

To systematically test our hypotheses, we estimate conditional logit models as described above. Table 3 presents the results for these models. Our hypotheses build on an established strand of literature which have already identified several factors related to MPs' chances of being appointed to ministerial posts. Our argument - that intraparty positioning, gender-typed committee affiliation, and the gender-type of the respective ministry matter in addition to these established variables, requires that overall, MPs are sanctioned for their deviating behavior. This expectation is evaluated in model 1 (Table 3).

The effect of our variable capturing how far away the position adapted by an MP in a policy field is located compared to the mean position of her partisan colleagues (deviation in policy field) has a highly significant negative effect, thus indicating that deviation from the party line decreases an MP's chances of being recruited for a ministerial post. Model 1 also shows a positive and significant effect for female MPs, which indicates that, on a general level, female MPs were more likely to be recruited as ministers. This finding relates directly to the informal rules of gender parity in Swedish cabinets described in the previous 
Table 3. Determinants of ministerial selection

\begin{tabular}{|c|c|c|c|}
\hline & Model 1 & Model 2 & Model 3 \\
\hline \multicolumn{4}{|l|}{ Main explanatory variables } \\
\hline Female MP & $\begin{array}{l}0.235^{* * *} \\
(3.27)\end{array}$ & $\begin{array}{r}0.137 \\
(0.91)\end{array}$ & 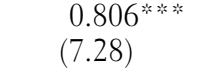 \\
\hline Deviation in policy field & 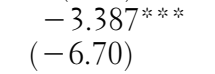 & 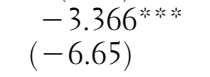 & $\begin{array}{l}-0.658 \\
(-1.09)\end{array}$ \\
\hline Female MP $\times$ deviation & & & $\begin{array}{l}-6.336^{\text {皮的 }} \\
(-6.80)\end{array}$ \\
\hline Member in feminine committee & $\begin{array}{l}-0.489^{\text {***; }} \\
(-3.92)\end{array}$ & $\begin{array}{l}-0.738^{* \ldots * k} \\
(-3.92)\end{array}$ & 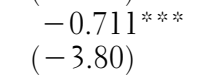 \\
\hline Member in masculine committee & $\begin{array}{l}-0.713^{* * * *} \\
(-6.09)\end{array}$ & $\begin{array}{l}-0.332^{*} \\
(-2.33)\end{array}$ & $\begin{array}{l}-0.287^{*} \\
(-2.01)\end{array}$ \\
\hline Female MP $\times$ feminine committee & & $\begin{array}{l}0.491^{\text {* }} \\
(1.99)\end{array}$ & $\begin{array}{r}0.470 \\
(1.90)\end{array}$ \\
\hline Female MP $\times$ masculine committee & & $\begin{array}{l}-0.999^{* * * *} \\
(-3.92)\end{array}$ & $\begin{array}{l}-1.072^{* * * *} \\
(-4.20)\end{array}$ \\
\hline Female MP $\times$ feminine ministry & & $\begin{array}{r}0.285 \\
(1.38)\end{array}$ & \\
\hline Female MP $\times$ masculine ministry & & $\begin{array}{c}0.154 \\
(0.89)\end{array}$ & \\
\hline \multicolumn{4}{|l|}{ Control variables } \\
\hline Party leadership position & $\begin{array}{l}2.880^{* * * * *} \\
(21.72)\end{array}$ & $\begin{array}{l}2.882^{* * * * *} \\
(21.71)\end{array}$ & $\begin{array}{l}2.886^{\text {**; }} \\
(21.64)\end{array}$ \\
\hline Age & $\begin{array}{l}-0.0574^{* \cdots *} \\
(-13.73)\end{array}$ & 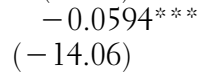 & $\begin{array}{l}-0.0612^{* * * *} \\
(-14.36)\end{array}$ \\
\hline Parliamentary tenure & $\begin{array}{l}0.0644^{\text {***; }} \\
(10.71)\end{array}$ & $\begin{array}{l}0.0656^{\text {粆济 }} \\
(10.83)\end{array}$ & 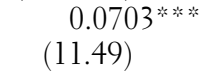 \\
\hline Academic education (binary) & $\begin{array}{l}0.183^{*} \\
(2.48)\end{array}$ & $\begin{array}{l}0.168^{*} \\
(2.26)\end{array}$ & $\begin{array}{l}0.166^{*} \\
(2.24)\end{array}$ \\
\hline Specialization in policy field & $\begin{array}{l}0.484^{*} \\
(2.23)\end{array}$ & $\begin{array}{l}0.448^{*} \\
(2.06)\end{array}$ & $\begin{array}{l}0.437^{*} \\
(1.99)\end{array}$ \\
\hline Prominence in plenary debates & 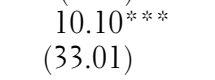 & $\begin{array}{l}10.09^{* * \cdots} \\
(33.05)\end{array}$ & 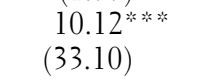 \\
\hline Standard Error in estimated position & $\begin{array}{l}1.934 \\
(1.75)\end{array}$ & $\begin{array}{l}1.698 \\
(1.53)\end{array}$ & $\begin{array}{l}1.861 \\
(1.65)\end{array}$ \\
\hline N & 13,297 & 13,297 & 13,297 \\
\hline
\end{tabular}

Note: Results from conditional logistic regression models. $z$ statistics are shown in parentheses. The dependent variable indicates whether an MP attained a ministerial portfolio. Groups are combinations of the government formation process and policy fields. The base categories for variables indicating female/male committee memberships or ministries are neutral ministries or committees, respectively. All models are restricted to MPs from the governing parties. Significance levels: ${ }^{*} p<0.05, * * p<0.01,{ }^{* * * *} p<0.001$.

section, that is, while cabinets exhibited (nearly) full gender parity, the share of female MPs in the Riksdag remained somewhat lower (approximately 44\%) during our observation period. This translates to the higher odds for female MPs of obtaining a ministerial post in our model. 
Beyond these two main findings, the model also indicates that the control variables work in an expected manner: The negative effect of age indicates that an MP's age decreases her chances of being selected as minister. However, the effect for parliamentary tenure is positive, which indicates that MPs' chances of being recruited for a ministerial post increase with the time they spent in parliament. Taken together, MPs who started their (parliamentary) careers early were the most likely candidates for ministerial recruitment, since they combined comparatively longer career durations with lower age. ${ }^{10}$

The variable measuring an academic education degree shows a positive significant effect for MPs who have completed tertiary education: ministers are selected from this group more frequently than from those who have less education. This finding is in line with previous ministerial selection studies in Sweden (Bäck et al. 2009).

Our measures for prominence indicate that an MP's status is an important aspect in ministerial selection. MPs occupying a party leadership position, that is, party leaders or parliamentary party group leaders, are roughly 3.5 times more likely to be recruited. The same applies for MPs who spoke frequently in plenary debates (prominence in plenary debates), which indicates that such MPs are key figures in their parties and are likely to secure ministerial posts if their parliamentary groups are involved in forming a government. Our final control variable, specialization in policy field, also indicates a significant and positive relationship. MPs who focus on a certain policy field in their plenary speeches, and are seen as "policy experts," are more likely to be appointed to ministerial offices in this particular policy area.

\section{Analyses of Ministerial Selection, Gender and Feminine Policy Fields}

Model 2 in Table 3 extends this baseline model for an evaluation of hypotheses 1 and 2 . The models therefore include binary variables and interactions for the gender types (feminine, masculine, and neutral) of the respective ministries and for the committees in which MPs served. To reiterate, our expectation from hypothesis $l$ is that female MPs are more likely to be recruited for ministries that fall into a female domain of policies, that is, those of a "feminine" gender type (Krook and O'Brien 2012). To evaluate this expectation, we include an interaction term between a group-level variable, the gender type of the relevant

10. Of course, this finding can be derived equivalently by including an MPs age at first entry. 
respective policy field, and an MP's gender. The effect for the interaction terms (female MP $\times$ feminine ministry and female $M P \times$ masculine ministry) both fail to attain statistical significance. ${ }^{11}$ The model thus indicates that female MPs are not generally more frequently recruited to ministries that can be considered as "feminine" policy domains and that they were also not less likely candidates for "masculine" ministries.

Turning to our second hypothesis, which states that female MPs with role-incongruent committee affiliations are less likely to succeed in securing a ministerial post, we find a positive effect for female MPs who were members of a feminine committee to be assigned a ministerial post and a negative effect for female MPs who were in masculine committees. ${ }^{12}$ Figure 2 graphically shows this relationship: for male MPs, the confidence intervals of the estimated effects for members of feminine, masculine, and neutral committees overlap, thus indicating that the gender type of their committees did not affect male MPs' chances to be selected as ministers. For female MPs, in contrast, those who were members of masculine committees are less likely to become ministers than their (female) colleagues in feminine or gender-neutral committees. This finding directly corresponds to the idea of role incongruity in the sense that female MPs with roleincongruent (i.e., masculine) committee memberships are less likely to attain ministerial posts, and this finding supports our second hypothesis.

\section{Analyses of Ministerial Selection, Gender, and Policy Positions}

The final model (model 3) includes an interaction effect to evaluate hypothesis 3, which says that we expect the effect of deviation from the party line to be conditional on an MP's gender. More precisely, we expect that when deviating, female MPs decrease their chances of being appointed to a ministerial position more strongly than male MPs decrease their chances. Interacting our deviation variable with the gender dummy captures this relationship. As indicated by model 3, the interaction effect (female MP $\times$ deviation) is negative and significant, which supports our hypothesis. Notably, when we include our interactions between gender and deviation, the interpretation for the noninteracted deviation variable changed. Whereas in models 1 and 2 deviations indicate an effect for both genders, the effect in model 3 is for

11. The base line category is neutral ministries.

12. The base line category is neutral committees. 


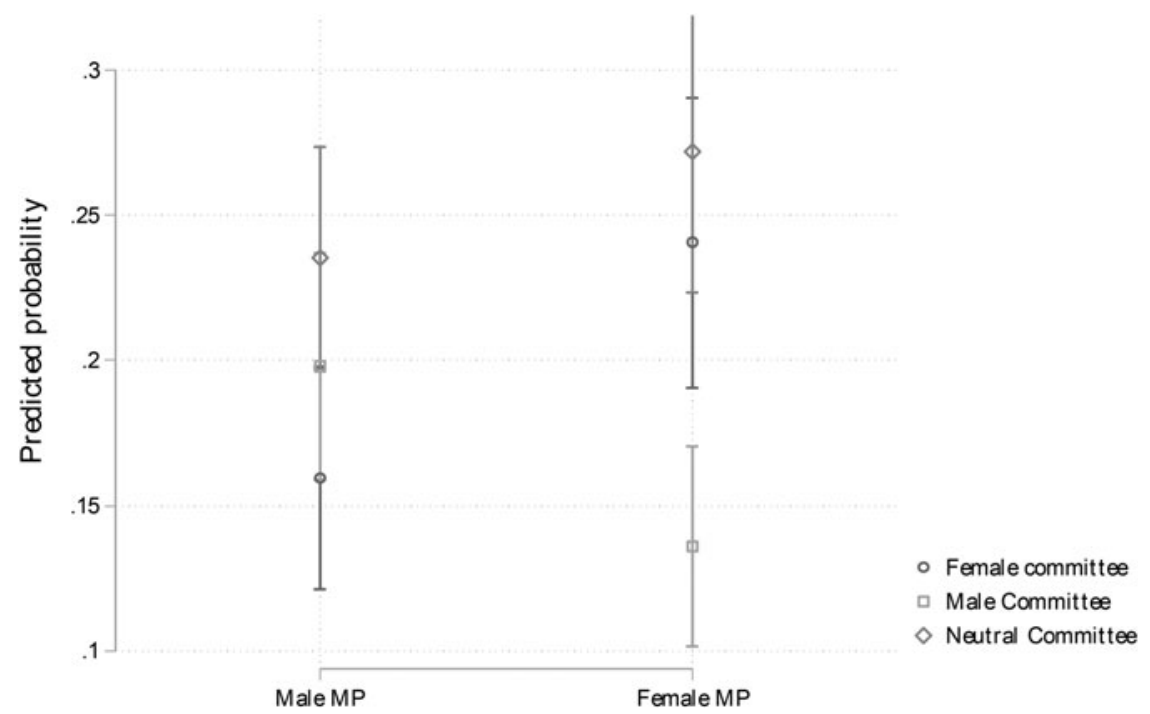

Figure 2. The effect of gender and committee gender types on ministerial selection.

Comment: Whiskers indicate 90\% confidence intervals.

male MPs only. Thus, model 3 indicates that male MPs who deviate from the party line in their speeches do not damage their chances of being recruited as ministers in these fields in a statistically significant way. Figure 3 presents the predictive margins for this relationship. ${ }^{13}$

As Figure 3 shows, deviation negatively affects the chances of female ministers, whereas for male MPs the negative effect is too small and the uncertainty too high to argue for a negative slope at any level of deviation. In contrast, female MPs' chances to attain ministerial posts quickly decline at low levels of deviation (i.e., below .2). At higher levels of deviation, our model even indicates a statistically significant difference between female and male MPs. Considering that most MPs did not deviate strongly (the point where our confidence intervals diverge is located roughly at the 90th percentile), this group- (or gender-) separating effect appears to be limited. Yet the slope for female MPs in Figure 2 indicates that deviation had a clear negative effect for female MPs, even when considering the small and medium levels of deviation

13. Since the regular principal component prediction is not suitable for conditional logit models, Figure 2 presents two alternative variants of prediction: The left-hand side panel gives a prediction under the assumption that the model fixed effects equal zero, and the right-hand panel uses a linear prediction. 

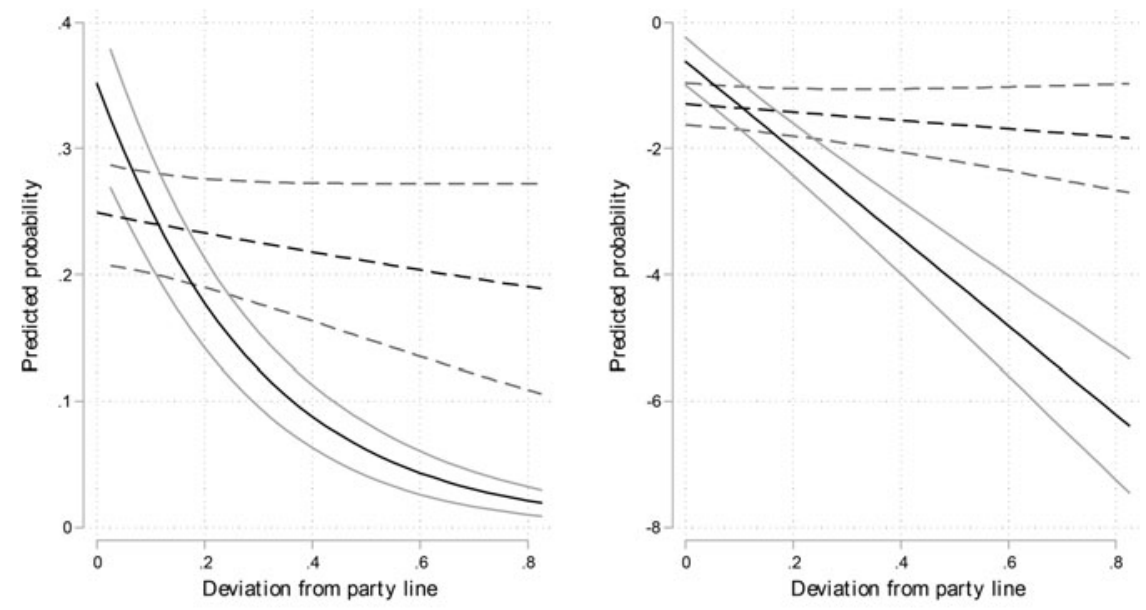

-- Male MP
- Female MP

FigurE 3. The effect of gender and deviations from the party line on ministerial selection.

Comment: Lighter lines indicate $90 \%$ confidence intervals.

where most observations are situated, whereas this effect is not present for male MPs. For nondeviating female MPs, chances of ministerial recruitment are, in fact, higher than for nondeviating male MPs. This situation reverses with increasing deviation so that deviating female MPs are less likely to be recruited than their deviating male colleagues.

This impression is also supported by a descriptive account: When focusing on the deviation of those MPs who were in fact recruited to ministerial posts, ministers who deviated more than the median MP were male by majority (58\%), whereas ministers who deviated below the median deviation were by majority female $(51 \%)$. Taken together, these data support our third hypothesis. Female MPs' chances of becoming ministers suffer more from deviation from the party line than do their male colleagues' chances. This finding suggests that female MPs are judged more harshly than their male counterparts, which is in line with the prediction drawn from role-congruity theory.

\section{CONCLUSION}

The selection of cabinet ministers is not subject to a popular vote, yet who becomes the citizens' representative in cabinet is crucial for democratic 
responsiveness since ministers are likely to influence policy output (see, e.g., Alexiadou 2016). Thus, it is important to understand the intraparty politics behind the selection of cabinet members. This study contributes to the literature on women's representation and gender biases in high offices by applying principal-agent theory, which has previously been used to explain ministerial selection. Following previous research (Bäck et al. 2016; Kam et al. 2010), we argued that intraparty politics matter for ministerial selection and that ministers are appointed with the aim of minimizing the policy distance to important principals. However, this logic of delegation does not operate identically for female and male candidates.

Our findings indicate that female MPs who previously were members of predominantly masculine committees have a lower likelihood of being selected to cabinet, suggesting that women's careers are hampered by holding such role incongruent positions in parliament. However, in relation to previous findings that have shown that female MPs are predominantly recruited to a certain category of ministries, which can be considered "feminine," we did not find robust empirical support in the case of Sweden. By analyzing how gender interacts with politicians' policy positions, we again found support for an expectation drawn from role-congruity theory that female and male political figures are evaluated differently. More specifically, we have shown that deviation from the party line is more harmful to a female MP's perspective of attaining a ministerial post than it is for male MPs.

One limitation of our analysis is that we are not able to analyze the complete pool of potential ministerial candidates since we have based our analysis on speeches made in parliament before appointment. There is no simple solution to this; it is impossible to know exactly from where ministers will be drawn. For example, in the Swedish case, some ministers have a background as former heavyweights in the labor union (see Bäck, et al. 2009), whereas others held important positions as civil servants or as university professors before becoming ministers (see Bäck and Persson 2018). As mentioned in the data and methods section, Sweden does not stand out in having more nonpolitician ministers than other European countries, with an average of $25 \%$ outsiders. Hence, this is a limitation facing scholars who apply the approach used here to other European countries (see, e.g., Bäck et al. 2016 for a comparative study using a similar approach). We still believe that this approach is useful, but it means that we must use caution when interpreting the results in this study. We cannot be certain that our conclusions about the role of 
gender in ministerial selection based on our results would hold if applied to a 'political outsider' sample.

Our findings have important implications for research on gender biases in political careers. First, the reduced tolerance for deviating female MPs implies that female ministerial candidates, that is MPs, are more constrained in the standpoints they can adopt. When facing a higher risk of being sanctioned, this may create an incentive not to deviate. Second, given that Sweden is a case where female and male MPs and cabinet members are more or less at parity, and given that Sweden is generally considered a model case for female representation, our findings imply that gender biases may exist despite high levels of female representation. Put differently, focusing solely on the share of female MPs and ministers may overlook important gender biases present in countries with otherwise high representation of women. This study is, to our knowledge, the first attempt to systematically identify gender biases in the process of selecting ministers from a larger pool of MPs. Our findings thus imply that these gendered selection processes exist and that similar gendered processes may extend to the other selection processes relevant to MPs' careers. These findings have important implications for our understanding of the processes by which individuals are chosen to the highest offices in parliamentary democracies.

\section{REFERENCES}

Alexiadou, Despina. 2016. Ideologues, Partisans, and Loyalists: Ministers and Policymaking in Parliamentary Cabinets. Oxford: Oxford University Press.

Bäck, Hanna, Patrick Dumont, Henk Erik Meier, Thomas Persson, and Kåre Vernby. 2009. "Does European Integration Lead to a Presidentialization of Executive Politics? Ministerial Selection in Swedish Postwar Cabinets." European Union Politics 10 (2): 226-252.

Bäck, Hanna, Thomas Persson, Kåre Vernby, and Helena Wockelberg. 2009. “In Tranquil Waters? Swedish Cabinet Ministers in the Post-War Era." In The Selection of Ministers in Europe: Hiring and Firing, ed. Keith Dowding and Patrick Dumont. London: Routledge.

Bäck, Hanna, Marc Debus, and Patrick Dumont. 2011. "Who Gets What in Coalition Governments? Predictors of Portfolio Allocation in Parliamentary Democracies." European Journal of Political Research 50 (4): 441-78.

Bäck, Hanna, and Torbjörn Bergman. 2016. “The Parties in Government Formation.” In The Oxford Handbook of Swedish Politics, ed. Jon Pierre. Oxford: Oxford University Press.

Bäck, Hanna, and Marc Debus. 2016. Political Parties, Parliaments and Legislative Speechmaking. Houndsmills: Palgrave Macmillan.

Bäck, Hanna, Marc Debus, and Wolfgang Müller. 2016. "Intraparty Diversity and Ministerial Selection in Coalition Governments." Public Choice 166:355-78. 
Bäck, Hanna, and Thomas Persson. 2018. "No More Political Insiders? Ministerial Selection in Sweden During the Post-WWII Period." In Technocratic Ministers and Political Leadership in European Democracies, ed. Antonio Costa Pinto, Maurizio Cotta, and Pedro Tavares de Almeida. New York: Palgrave.

Baumann, Markus, Marc Debus, and Jochen Müller. 2015. "Personal Characteristics of MPs and Legislative Behavior in Moral Policy Making." Legislative Studies Quarterly 40 (2): 179-210.

Baumann, Markus, Marc Debus, and Tristan Klingelhöfer. 2017. "Keeping One’s Seat. The Competitiveness of MP Renomination in Mixed-Member Electoral Systems." The Journal of Politics 79 (3): 979-994.

Bergman, Torbjörn, Wolfgang C. Müller, Kaare Strøm, and Magnus Blomgren. 2003. "Democratic Delegation and Accountability: Cross-National Patterns." In Delegation and Accountability in Parliamentary Democracies, ed. Kaare Strøm, Wolfgang C. Müller, and Torbjörn Bergman, 109-220. Oxford: Oxford University Press.

Bernauer, Julian, and Thomas Bräuninger. 2009. "Intraparty Preference Heterogeneity and Faction Membership in the 15th German Bundestag. A Computational Text Analysis of Parliamentary Speeches." German Politics 18 (3): 385-402.

Blondel, Jean and Jean-Louis Thiébault, eds. 1991. The Profession of Government Minister in Western Europe. London: MacMillan.

Blumberg, Rae Lesser. 1984. "A General Theory of Gender Stratification.” Sociological Theory 2:23-101.

Bolzendahl, Catherine. 2014. "Opportunities and Expectations: The Gendered Organization of Legislative Committees in Germany, Sweden, and the United States." Gender \& Society 28:847-76.

Brescoll, Victoria L., Erica Dawson, and Eric Luis Uhlman. 2010. "Hard Won and Easily Lost: The Fragile Status of Leaders in Gender-Stereotype-Incongruent Occupations.” Psychological Science 21 (11): 1640-42.

Carey, John M. 2007. "Competing Principals, Political Institutions, and Party Unity in Legislative Voting.” American Journal of Political Science 51 (1): 92-107.

Carroll, Royce, Gary W. Cox, and Monica Pachón. 2006. "How Parties Create Electoral Democracy, Chapter 2." Legislative Studies Quarterly 31(2): 153-74.

Carroll, Royce, and Keith Poole. 2014. "Roll Call Analysis and the Study of Legislatures." In The Oxford Handbook of Legislative Studies, ed. Shane Martin, Thomas Saalfeld, and Kaare W. Strøm. Oxford: Oxford University Press.

Cotta, Maurizio. 2018. “Technocratic Government Versus Party Government? Nonpartisan Ministers and the Changing Parameters of Political Leadership in European Democracies." In Technocratic Ministers and Political Leadership in European Democracies, ed. Antonio Costa Pinto, Maurizio Cotta, and Pedro Tavares de Almeida. Basingstoke, UK: Palgrave.

Davis, Rebecca Howard. 1997. Women and Power in Parliamentary Democracies: Cabinet Appointments in Western Europe, 1968-1992. Lincoln: University of Nebraska Press.

De Winter, Lieven. 1991. "Parliamentary and Party Pathways to the Cabinet." In The Profession of Government Minister in Western Europe, ed. Jean Blondel and JeanLouis Thiébault, 44-69. Basingstoke, UK: Palgrave.

Dowding, Keith, and Patrick Dumont. 2008. "Structural and Strategic Factors Affecting the Hiring and Firing of Ministers." In The Selection of Ministers in Europe, ed. Patrick Dumont and Keith Dowding. London: Routledge.

- eds. 2009. The Selection of Ministers in Europe: Hiring and Firing. London: Routledge.

Eagly, Alice H., and Steven J. Karau. 2002. "Role Congruity Theory of Prejudice Toward Female Leaders." Psychological Review 109 (3): 573-98. 
Eagly, Alice H., Mona G. Makhijani, and Bruce G. Klonsky. 1992. "Gender and the Evaluation of Leaders: A Meta-Analysis." Psychological Bulletin 111 (1): 3-22.

Escobar-Lemmon, Maria, and Michelle M. Taylor-Robinson. 2005. "Women Ministers in Latin American Government: When, Where, and Why?" American Journal of Political Science 49 (4): 829-44.

- 2009. "Getting to the Top: Career Paths of Women in Latin American Cabinets." Political Research Quarterly 62 (4): 685-99.

Gallagher, Michael, Michael Laver, and Peter Mair. 1995. Representative Government in Modern Europe. Maidenhead: McGraw-Hill.

Giannetti, Daniela, and Michael Laver. 2009. "Party Cohesion, Party Discipline, and Party Factions in Italy." In Intraparty Politics and Coalition Governments in Parliamentary Democracies, ed. Daniela Giannetti and Kenneth Benoit. London: Routledge.

Indridason, Indridi H., and Christopher Kam. 2008. "Cabinet Reshuffles and Ministerial Drift." British Journal of Political Science, 38 (4): 621-56.

Iversen, Torben, and Frances Rosenbluth. 2008. "Work and Power: The Connection Between Female Labor Force Participation and Female Political Representation." Annual Review of Political Science 11:479-95.

Kam, Christopher, William T. Bianco, Itai Sened, and Regina Smyth. 2010. "Ministerial Selection and Intraparty Organization in the Contemporary British Parliament." American Political Science Review 104 (2): 289-306.

Kite, Mary E., Kay Deaux, and Elizabeth L. Haines. 2008. "Gender Stereotypes." In Psychology of Women: A Handbook of Issues and Theories, ed. Florence L. Denmark and Michele A. Paludi. Westport, CT: Praeger.

Krehbiel, Keith. 2000. "Party Discipline and Measures of Partisanship." American Journal of Political Science 44 (2): 212-27.

Krook, Mona Lena, and Diana Z. O’Brien. 2012. “All the President's Men? The Appointment of Female Cabinet Ministers Worldwide." Journal of Politics 74 (3): 840-55.

Laver, Michael, and Kenneth Benoit. 2002. "Locating TDs in Policy Spaces: Wordscoring Dáil Speeches." Irish Political Studies 17 (1): 59-73.

Laver, Michael, Kenneth Benoit, and John Garry. 2003. "Extracting Policy Positions from Political Texts Using Words as Data." American Political Science Review 97:311-31.

Lawless, Jennifer L. 2015. "Female Candidates and Legislators." Annual Review of Political Science 18:349-66.

Lindvall, Johannes, Hanna Bäck, Carl Dahlström, Elin Naurin, and Jan Teorell. 2017. Samverkan och strid i den parlamentariska demokratin. Stockholm: SNS Förlag.

Mair, Peter. 1997. Party System Change: Approaches and Interpretations. Oxford: Clarendon Press.

Martin, Shane. 2012. "Why Electoral Systems Don't Always Matter. The Impact of 'MegaSeats' on Legislative Behaviour in Ireland." Party Politics 20 (3): 467-79.

McCarty, Nolan, Keith Poole, and Howard Rosenthal. 2006. Polarized America. The Dance of Ideology and Unequal Riches. Cambridge, MA: MIT Press.

Niven, David. 1998. The Missing Majority: The Recruitment of Women as State Legislative Candidates. Westport, CT: Praeger.

O'Brien, Diana Z. 2015. "Rising to the Top: Gender, Political Performance, and Party Leadership in Parliamentary Democracies." American Journal of Political Science 59 (4): $1022-39$.

Polk, Jonathan, Jan Rovny, Ryan Bakker, Erica Edwards, Liesbet Hooghe, Seth Jolly, Jelle Koedam, Filip Kostelka, Gary Marks, Gijs Schumacher, Marco Steenbergen, Milada Vachudova, and Marko Zilovic. 2017. "Explaining the Salience of Antielitism and Reducing Political Corruption for Political Parties in Europe with the 2014 Chapel Hill Expert Survey Data." Research \& Politics 4 (1): 1-9. 
Poole, Keith T., and Howard Rosenthal. 1997. Congress: A Political-Economic History of Roll Call Voting. New York, Oxford: Oxford University Press.

Reynolds, Andrew. 1999. "Women in the Legislatures and Executives of the World: Knocking at the Highest Glass Ceiling." World Politics 51 (4): 547-72.

Rudman, Laurie A. 1998. "Self-Promotion as a Risk Factor for Women: The Costs and Benefits of Counter-Stereotypical Impression Management." Journal of Personality \& Social Psychology 74:629-45.

Rudman, Laurie A., and Peter Glick. 2001. "Prescriptive Gender Stereotypes and Backlash Toward Agentic Women." Journal of Social Issues 57:743-62.

Sanbonmatsu, Kira. 2006. Where Women Run: Gender and Party in the American States. Ann Arbor: University of Michigan Press.

Siaroff, Alan. 2000. "Women's Representation in Legislatures and Cabinets in Industrial Democracies." International Political Science Review 21 (2): 197-215.

Strøm, Kaare. 2000. "Delegation and Accountability in Parliamentary Democracies." European Journal of Political Research 37:261-289.

Studlar, Donley T., and Gary F. Moncrief. 1997. "The Recruitment of Women Cabinet Ministers in the Canadian Provinces." Governance 10 (1): 67-81.

Willumsen, David M., and Patrik Öhberg. 2017. "Toe the line, break the whip: explaining floor dissent in parliamentary democracies." West European Politics 40 (4): 688-716.

Wängnerud, Lena. 2015. The Principles of Gender-Sensitive Parliaments. London: Routledge.

\section{APPENDIX}

Table Ala. Feminine, masculine and neutral ministries

\begin{tabular}{lll}
\hline Feminine Ministries & \multicolumn{1}{c}{ Masculine Ministries } & \multicolumn{1}{c}{ Neutral Ministries } \\
\hline Social affairs & Agriculture & Civil service \\
Health & Fisheries, sea & Energy \\
Family, youth & Postal service, & Environment \\
& Telecommunication & \\
Education & Research, technology & Justice \\
Women, equal & Construction, housing, & Relations with parliament \\
opportunities & Urbanization & \\
Culture & Interior & Public works \\
Foreign aid & Defense & Planning, land management \\
& Finance/treasury/budget & Regional affairs \\
& Economy & Sports \\
& Foreign affairs & Leisure, tourism \\
& Labor, employment & War veterans, refugees, and \\
& repatriation \\
& Transport & Consumer affairs \\
& Information & Food \\
& European affairs & \\
& Industry & \\
& Foreign trade &
\end{tabular}


Table Alb. Feminine, masculine and neutral parliamentary committees

\begin{tabular}{lll}
\hline Feminine Committees & \multicolumn{1}{c}{ Masculine Committees } & Neutral Committees \\
\hline Cultural affairs & Labor market & Civil affairs \\
Social insurance & Finance & Justice \\
Education & Defense & Constitution \\
Joint Justice and Social & Industry & Environment and \\
& & agriculture \\
Joint Foreign Affairs and & Taxation & \\
Social affairs) & Housing \\
Health and welfare & Transportation and & \\
& communication & \\
& Foreign affairs & \\
& European Union affairs & \\
& Joint Foreign Affairs and & \\
& Defense & \\
\hline
\end{tabular}

Table A2. Duration of periods underlying the speech scaling

\begin{tabular}{rrrrrr}
\hline Year & N & Mean & SD & Min & Max \\
\hline 1996 & 140 & 452 & 145 & 112 & 537 \\
1998 & 135 & 1,136 & 397 & 119 & 1,462 \\
2002 & 116 & 1,223 & 419 & 117 & 1,462 \\
2006 & 116 & 1,118 & 407 & 152 & 1,462 \\
2010 & 218 & 1,075 & 444 & 100 & 1,462 \\
2014 & 208 & 1,116 & 443 & 108 & 1,462 \\
\hline
\end{tabular}

Note: SD, standard deviation. Values in the second column are numbers of potential ministerial candidates, that is, legislators from the government party/parties. Values in the columns three to six are durations (lengths) of the periods underlying the scaling of speeches. Parliamentary speeches were only available from 1994 onward, which shortened observations for the 1996 cabinet formation process. 
Table A3. Gender and previous parliamentary experience among recruited ministers in Swedish cabinets

\begin{tabular}{|c|c|c|c|c|c|c|}
\hline & $\begin{array}{l}\text { Persson I, } \\
\text { No. (\%) }\end{array}$ & $\begin{array}{c}\text { Persson II, } \\
\text { No. }(\%)\end{array}$ & $\begin{array}{l}\text { Persson III, } \\
\text { No. (\%) }\end{array}$ & $\begin{array}{l}\text { Reinfeldt I, } \\
\text { No. }(\%)\end{array}$ & $\begin{array}{l}\text { Reinfeldt II, } \\
\text { No. }(\%)\end{array}$ & $\begin{array}{l}\text { Löfven, } \\
\text { No. (\%) }\end{array}$ \\
\hline \multicolumn{7}{|l|}{ Never an MP } \\
\hline Male & $5(22.73)$ & $4(19.05)$ & $3(13.64)$ & $1(4.545)$ & $1(4.167)$ & $1(4.167)$ \\
\hline Female & $2(9.091)$ & $3(14.29)$ & $5(22.73)$ & $3(13.64)$ & $1(4.167)$ & $6(25)$ \\
\hline Total & $7(31.82)$ & $7(33.33)$ & $8(36.36)$ & $4(18.18)$ & $2(8.333)$ & $7(29.17)$ \\
\hline \multicolumn{7}{|c|}{ MP at appointment } \\
\hline Male & $3(13.64)$ & $3(14.29)$ & $5(22.73)$ & $8(36.36)$ & $2(8.333)$ & $10(41.67)$ \\
\hline Female & $2(9.091)$ & $0(0)$ & $1(4.545)$ & $6(27.27)$ & $1(4.167)$ & $4(16.67)$ \\
\hline Total & $5(22.73)$ & $3(14.29)$ & $6(27.27)$ & $14(63.64)$ & $3(12.50)$ & $14(58.33)$ \\
\hline \multicolumn{7}{|l|}{ MP earlier } \\
\hline Male & $3(13.64)$ & $4(19.05)$ & $4(18.18)$ & $3(13.64)$ & $10(41.67)$ & $1(4.167)$ \\
\hline Female & $7(31.82)$ & $7(33.33)$ & $4(18.18)$ & $1(4.545)$ & $9(37.50)$ & $2(8.333)$ \\
\hline Total & $10(45.45)$ & $11(52.38)$ & $8(36.36)$ & $4(18.18)$ & $19(79.17)$ & $3(12.50)$ \\
\hline \multicolumn{7}{|l|}{ All experiences } \\
\hline Male & $11(50)$ & $11(52.38)$ & $12(54.55)$ & $12(54.55)$ & $13(54.17)$ & $12(50)$ \\
\hline Female & $11(50)$ & $10(47.62)$ & $10(45.45)$ & $10(45.45)$ & $11(45.83)$ & $12(50)$ \\
\hline Total & $22(100)$ & $21(100)$ & $22(100)$ & $22(100)$ & $24(100)$ & $24(100)$ \\
\hline Observations & 22 & 21 & 22 & 22 & 24 & 24 \\
\hline
\end{tabular}

Note: Values are numbers of ministers with the respective gender and recruitment background in each of the cabinets who were recruited during cabinet formation processes between 1996 and 2014. 